\title{
PEMBERDAYAAN EKONOMI MASYARAKAT PETANI MELALUI PENGOLAHAN LABU KUNING (CURCUBITA MOCHATA) MENJADI PRODUK CEMILAN DI DESA BARAKATI KABUPATEN GORONTALO
}

\author{
Citron Supu Payu1* ${ }^{*}$, Yulinda Lubis Ismail ${ }^{2}$, Syam Salim Kumaji ${ }^{3}$

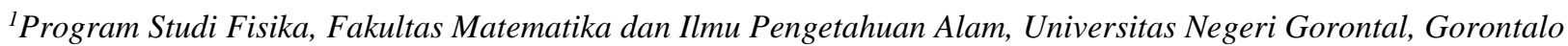 \\ ${ }^{2}$ Program Studi Manajemen, Fakultas Ekonomi, Universitas Negeri Gorontal, Gorontalo \\ ${ }^{3}$ Program Studi Biologi, Fakultas Matematika dan Ilmu Pengetahuan Alam, Universitas Negeri Gorontal, \\ Gorontalo \\ *Penulis Korespondensi: citronpayu@gmail.com
}

\begin{abstract}
Abstrak
Tujuan dari program ini adalah meningkatkan nilai ekonomi komoditas labu kuning di Desa Barakati, Kecamatan Batudaa Kabupaten Gorontalo. Penjualan bahan mentah Labu Kuning dinilai masih terkendala dalam proses distribusi/penjualan yang hanya terbatas di pasaran tradisional. Upaya yang dilakukan adalah melalui pengolahan bahan mentah Labu Kuning menjadi produk cemilan yang enak dan bergizi, serta memiliki nilai jual yang berkompeten dipasaran. Adapun metode yang digunakan dalam program ini adalah metode penyuluhan dan pelatihan. Program ini bekerja sama dengan UP. FMA Desa barakati sebagai mitra dalam pusat pengolahan labu kuning menjadi cemilan dan Plaza Amanda Jaya Gorontalo sebagai mitra dalam proses pemasaran produk cemilan. Alur kegiatan meliputi tahap persiapan berupa observasi ke dinas / instansi terkait dan pembekalan mahasiswa KKN-PPM. Kemudian tahap pelaksanaan, yaitu penyuluhan dan pelatihan pada masyarakat di 4 dusun yakni Dusun I Hungayo, Dusun II Botuhuwayo, Dusun III Hutamela, dan Dusun IV Bontula, yang berpusat di UP-FMA Desa Barakati. Dengan adanya partisipasi langsung oleh masyarakat, diharapkan muncul ide-ide baru dan kreatif oleh masyarakat dalam mengolah Labu Kuning sehingga program ini dapat berkelanjutan sebagai upaya konkrit untuk terus meningkatkan ekonomi masyarakat setempat.
\end{abstract}

Kata Kunci : Labu Kuning, Cemilan

\begin{abstract}
This program aims at increasing the economic value of pumpkin commodity in Barakati village of Batudaa sub-district, Gorontalo regency. The sales of raw pumpkin is still low due to its distribution which was only distributed among traditional markets. In order to increase its economic value, this pumpkin has to be processed into delicious and nutritious snacks that can be marketed in wider market. This study used training and socialization methods. This study was conducted in cooperation with UP. FMA of Barakati village as the partner in processing these pumpkin into snacks. It was also conducted in cooperation with Plaza Amanda Jaya Gorontalo as the partner in marketing the snacks produced from pumpkin. This program was preceded by preparation stage through observation to related stakeholders and preparing students who will participate in KKN-PPM program. The implementation program, namely the socialization and community trainings were conducted our hamlets namely, Dusun I Hungayo, Dusun II Botuhuwayo, Dusun III Hutamela, and Dusun IV Bontula. This training was focused in UP-FMA Barakati village. Through direct community participation it is expected that there will be new ideas arise from community in processing these pumpkin, hence this program would be sustainable and can be a concrete effort in increasing the economy and livelihood of the local community.
\end{abstract}

Keywords: Pumpkin, Snacks

\section{PENDAHULUAN}

Desa Barakati merupakan salah satu Desa dari 8 Desa yang berada di kecamatan Batudaa yang berdasarkan letak geografis berada disebelah barat dari Desa Iluta dengan luas 346 Ha. Dengan kondisi Tofografi alam Desa Barakati, sebagaimana di desa- desa lain mempunyai iklim kemarau dan penghujan.Desa Barakati terbagi dalam 4 Dusun yaitu Dusun Hungayo, Dusun Botuhuwayo, Dusun Hutamela, dan Dusun Bontula. Pada aspek demografis, pada tahun 2009 Desa Barakati memiliki penduduk sejumlah 2115 jiwa, tahun tahun 2010 
sejumlah 2163, tahun 2011 sejumlah 2166, tahun 2012 sejumlah 2213.

Keadaan perekonomian di Desa Barakati lebih didominasi oleh sektor pertanian dan nelayan. Dari data yang ada lahan pertanian yang ada di desa ini adalah seluas 77.50 Ha diwilayah dusun Hungayo, Dusun Botuhuwayo, Dusun Botuhuwayo, Dusun Hutamela dan Dusun Bontula dan lahan nelayan seluas 3 Ha di wilayah Dusun Hungayo. Dari sektor pertanian terdapat banyak komoditi yang memiliki tingkat hasil panen yang cukup besar, atau sangat berpotensi. Salah satu Komoditas sektor pertanian yang berpotensi tersebut adalah komoditas pertanian labu kuning (waluh).

Labu Kuning, tumbuhan bernama latin Curcubita mochata merupakan salah satu komoditas pertanian yang memiliki banyak kelebihan dibandingkan dengan komoditas yang lain (Gardjito:2006). Labu Kuning merupakan jenis sayuran buah yang memiliki daya simpan tinggi, mempunyai aroma dan citarasa yang khas, serta sumber vitamin A karena kaya akan karoten selain mengandung gizi-gizi lainnya seperti karbohidrat, mineral, protein, dan vitamin (Usmiati dan Setiyanto: 2005).

Labu Kuning atau waluh merupakan bahan pangan yang kaya vitamin $\mathrm{A}, \mathrm{B}$, dan $\mathrm{C}$, mineral, serta karbonhidrat namun Labu Kuning tidak tinggi kalori sehingga tidak mengkhawatirkan bagi yang sedang diet rendah kalori. Dalam 100gram Labu Kuning hanya mengandung 29 kalori sehingga cukup aman dikonsumsi walaupun sudah diberi beberapa bahan penunjang seperti tepung terigu atau beras. Daging buahnya pun mengandung antioksidan sebagai penangkal berbagai jenis kanker. Sifat Labu Kuning yang lunak dan mudah dicerna serta mengandung karoten (pro vitamin A) cukup tinggi, serta dapat menambah warna menarik dalam olahan pangan lainnya. Tetapi sejauh ini pemanfaatannya belum optimal. Umumnya Labu Kuning hanya diolah menjadi kolak ataupun sayuran. Penyebabnya adalah terbatasnya pengetahuan masyarakat akan manfaat komoditas pangan tersebut. (Widayati, 2007). Kandungan gizi pada Labu Kuning terdapat pada Tabel 1.

Tabel 1. Kandungan Gizi pada Labu Kuning

\begin{tabular}{|c|l|r|}
\hline No. & Kandungan Gizi & Kadar \\
\hline 1 & Energi (kal) & 2,9 \\
\hline 2 & Protein (g) & 1,1 \\
\hline 3 & Lemak (g) & 0,3 \\
\hline 4 & Karbohidrat /pati (g) & 6,6 \\
\hline 5 & Kalsium (mg) & 4,5 \\
\hline 6 & Fosfor (mg) & 64,0 \\
\hline 7 & Zat besi (mg) & 1,4 \\
\hline 8 & Vitamin A (SI) & 180,0 \\
\hline 9 & Vitamin B (mg) & 0,9 \\
\hline 10 & Vitamin C (mg) & 52,0 \\
\hline 11 & Air (\%) & 91,2 \\
\hline 12 & BDD (\%) & 77,0 \\
\hline
\end{tabular}

Sumber: (Sudarto, 2000: 16)
Desa Barakati merupakan salah satu daerah yang memiliki potensi Labu Kuning yang cukup luas dengan sebagian besar komoditas pertaniannya adalah Labu Kuning. Seperti yang diungkapkan oleh salah satu petani Labu Kuning di Desa Barakati, Bapak Halid mengatakan bahwa produksi Labu Kuning dalam sekali panen di lahan pertanian beliau yang seluas 2 hektar adalah sekitar 60 ton. Produksi tersebut ternilai cukup besar untuk skala panen Labu Kuning rata-rata di Indonesia. Akan tetapi, produksi yang besar ini akan lebih baik jika diimbangi dengan tingkat distribusi/pemasaran yang besar pula. Sesuai hasil wawancara dengan para petani Labu kuning di desa Barakati, semua petani mengatakan bahwa hasil panen Labu Kuning dijual langsung dipasar-pasar tradisional. Salah seorang Petani mengungkapkan bahwa hasil pemasaran dari buah Labu Kuning tidak terlalu besar. Hal ini mungkin dikarenakan peminat Labu Kuning khususnya di daerah Gorontalo tergolong cukup rendah. Bahkan peminatnya pun hanya terbatas untuk mengolah Labu Kuning sebagai bahan tambahan dalam makanan pokok.

Dari uraian diatas, terlihat bahwa masalah utamanya yaitu terdapat pada tingkat pemasaran Labu Kuning yang masih tergolong cukup rendah. Hal ini dikarenakan para Petani Labu Kuning hanya menjual produknya berupa bahan mentah Labu Kuning langsung ke pasar tradisional. Adapun solusi yang ditawarkan adalah dengan mengolah buah Labu Kuning menjadi olahan makanan berupa Cemilan yang Enak dan Bergizi dan tentunya memiliki nilai jual yang cukup berkompeten.

Makanan ringan atau cemilan merupakan makanan yang dapat menghilangkan rasa lapar seseorang sementara waktu. Faktanya dapat kita lihat disepanjang jalan khususnya dikota Gorontalo, banyak outlet yang menjual makanan ringan dengan berbagai rasa dan bahan dasar. Perkembangan ini disebabkan mulai dari tingginya kebutuhan masyarakat akan makanan ringan (kegemaran ngemil) dan keinginan masyarakat untuk menikmati rasa-rasa yang berbeda yang ditawarkan oleh produsen pada makanan dengan penampilan yang menarik serta harga yang terjangkau, maka satu keputusan yang tepat untuk meramaikan dunia industri makanan ringan.

Produk yang termasuk dalam kategori makanan ringan menurut Surat keputusan Kepala Badan Pengawas Obat Dan Makanan Republik Indonesia No. HK.00.05.52.4040 tanggal 9 Oktober 2006 tentang Kategori Pangan adalah semua makanan ringan yang berbahan dasar kentang, umbi, serealia, tepung atau pati (dari umbi dan kacang) dalam bentuk krupuk, kripik, jipang dan produk ekstrusi seperti chiki-chikian. Selain itu produk olahan kacang, termasuk kacang terlapisi dan campuran kacang (contoh dengan buah kering) serta makanan ringan berbasisikan (dalam bentuk kerupuk atau keripik) juga masuk kedalam kategori makanan ringan.

Kebutuhan akan makanan merupakan salah satu kebutuhan pokok yang wajib dipenuhi karena makanan merupakan sumber tenaga untuk menjalani aktivitas. Namun terkadang makanan menjadi 
menakutkan salah satunya makanan ringan atau yang sering disebut cemilan. Sebagian orang sangat menghindari makanan ringan ini, karena dianggap tidak baik untuk kesehatan.

\section{BAHAN DAN METODE}

Metode yang digunakan yaitu metode observasi partisipatif terhadap objek dimana penulis mengamati dan terlibat langsung dalam setiap langkah kerjanya. Di samping itu dilakukan wawancara dengan pembimbing lapangan serta karyawan yang bekerja dilokasi pengamatan. Wawancara dilakukan kepada sumber yang memilki kapasitas untuk memberikan jawaban mengenai proses pengolahaan kue yang berbahan baku labu kuning yang dilakukan di UPFMA Desa Barakati dengan tujuan menggali informasi secara tepat dan akurat. Langkah-langkah dalam bentuk program yang akan dilaksanakan adalah program produksi pembuatan Cemilan. Metode yang digunakan dalam melakukan pemberdayaan kelompok sasaran adalah pembelajaran teknik membuat Cemilan yang berkualitas disertai teori dan praktek langsung. Pembelajaran disertai praktek akan dilakukan oleh mahasiswa bersama-sama dengan kelompok sasaran yang juga didampingi oleh mitra yang professional di bidangnya. Berdasarkan panduan edisi XI 2017 Dikti dan Pedoman pelaksanaan KKS di Universitas Negeri Gorontalo 2017, maka alur pelaksanaan kegiatan diberikan seperti pada diagram dibawah ini :

\begin{tabular}{|c|}
\hline $\begin{array}{c}\text { Koordinasi Tim, dengan Dinas Instansi terkait } \\
\text { dan Pemerintah setempat dan Kelompok sasaran }\end{array}$ \\
\hline $\begin{array}{c}\text { Kegiatan inti sosialisasi dan pelatihan pengolahan } \\
\text { labu kuning menjadi cemilan }\end{array}$ \\
\hline $\begin{array}{c}\text { Monitoring dan evaluasi pembuatan, distribusi } \\
\text { dan hasil pemasaran cemilan }\end{array}$ \\
\hline $\begin{array}{c}\text { Hasil pengabdian meningkatkan ekonomi } \\
\text { masyarakat petani labu kuning }\end{array}$ \\
\hline \begin{tabular}{c} 
Gambar 1. Alur pelaksanaan program KKN-PPM \\
\hline
\end{tabular}
\end{tabular}

\section{HASIL DAN PEMBAHASAN}

Berdasarkan implementasi program KKN-PPM di lapangan maka hasil dan pembahasannya diuraikan sebagai berikut: 1) Pendampingan program telah dilakukan selama kurang lebih dua bulan yang telah memberikan dampak pada meningkatnya pemanfaatan labu kuning yang melimpah sebagai produk cemilan khas dari desa Barakati. 2) Dengan meningkatnya pemanfaatan labu kuning sebagaimana poin satu di atas maka kondisi tersebut berdampak pada meningkatnya pula minat dari petani lokal setempat untuk kembali membudidayakan dan mengembangkan tanaman labu kuning sebagai potensi yang dapat meningkatkan pendapatan petani. 3) Meningkatnya keterampilan kelompok pengrajin dalam pengolahan labu kuning di desa Barakati. 4) Bertambahnya pemahaman dan pengetahuan kelompok pengrajin dalam memenuhi standar produksi labu kuning sebagai cemilan yang sehat dan higienis ragam rasa sebagai ciri khas desa Barakati. 5) Meningkatnya pemahaman dan praktek pemasaran ragam produk cemilan labu kuning sesuai permintaan pasar di Gorontalo. 6) Bertambahnya omzet penjualan sebagai akibat dari perbaikan manajemen kelompok secara bertahap dan terukur. 7) Bagi mahasiswa memperoleh pengalaman empirik di lapangan tentang berbagai masalah mendasar yang dihadapi masyarakat sekaligus berupaya membuat analisis dan solusi konkrit dalam pemecahan masalah secara bertahap dan terukur. 8) Bagi pemerintah setempat dapat memberdayakan masyarakat petani labu kuning, meningkatkan produktivitas kelompok, sedikitnya mengurangi tingkat pengangguran dan menggerakkan ekonomi masyarakat setempat. 9) Bagi perguruan tinggi merupakan bentuk kepedulian pada lingkungan masyarakat melalui program pengabdian masyarakat. 10) Bagi tim dosen pelaksana merupakan bentuk nyata karya praktek yang berkolaborasi dengan mahasiswa dan masyarakat dalam memecahkan masalah pemberdayaan ekonomi masyarakat setempat dalam skala mikro secara mendasar, bertahap dan terukur.

Disamping itu pula tim pelaksana menyelenggarakan kegiatan inti dalam bentuk bimbingan teknis pengolahan labu kuning menjadi ragam produk cemilan yang sehat dan higienis ciri khas desa Barakati, dengan materi sebagai berikut:

1. Materi Pertama: Potensi Labu kuning dan Berbagai Permasalahan yang dihadapi Petani di Desa Barakati Kecamatan Batudaa Kabupaten Gorontalo. Materi ini mengungkapkan berbagai potensi ril yang dimiliki desa salah satunya labu kuning yang banyak terdapat di wilayah ini. Disamping itu pula diuraikan secara rinci berbagai masalah yang dihadapi oleh petani dan kelompok masyarakat pengolah labu kuning, baik masalah produksi dan pemasaran. Oleh karena itu melalui KKN-PPM berbagai masalah diurai secara rinci dan ditempuh solusi konkrit pemecahan masalah. Hasil positifnya potensi dapat dikembangkan dan memberikan manfaat dalam meningkatkan kesejahteraan petani dan kelompok masyarakat sebagai pengolah ragam produk cemilan labu kuning.

2. Materi Kedua: Sinergi Pemeritah dan Perguruan Tinggi Serta Masyarakat Dalam Upaya Pemberdayaan dan Peningkatan Kesejahteraan Kelompok Petani dan pengolah labu kuning. Materi ini menegaskan pentingnya peran perguruan tinggi dalam mengiplementasikan program Tri Dharma Perguruan Tinggi, khususnya pengabdian masyarakat. Sebagai lembaga tinggi yang mengembangan ilmu pengetahuan dan teknologi maka mutlak dibutuhkan peran perguruan tinggi dalam mengangkat dan mengembangkan potensi wilayah, khususnya potensi labu kuning yang melimpah di desa Barakati Kecamatan Batudaa Kabupaten Gorontalo. Hasilnya menunjukkan program KKNPPM yang merupakan program dukungan Kemristek Dikti R.I telah membuka harapan dan 
peluang bagi pemberdayaan masyarakat melalui pengolahan labu kuning secara berkelanjutan.

3. Materi Ketiga: Penataan Administrasi Usaha dan Penataan Kelembagaan Organisasi/Kelompok Pengolah. Dalam materi ini ditegaskan tentang perlunya pennyusunan rencana kegiatan secara ril, penyusunan tahapan rencana secara sistematis, pembagian tugas kelompok, pemenuhan kebutuhan operasional kelompok, pembahasan dan praktek peraturan dalam pengelolaan kelompok usaha dan berbagai upaya dalam memperkuat komitmen dan kebersamaan kelompok untuk mencapai rencana target yang telah ditetapkan bersama secara bertahap dan terukur. Disamping itu pula diadakan simulasi kelompok dalam menghadapi berbagai tantangan yang mungkin ditemui baik secara internal maupun eksternal. Hasilnya menunjukkan meningkatnya pemahaman, kebersamaan dan komitmen sesama anggota kelompok dalam sinergi pengelolaan kelompok usaha secara berkelanjutan.

4. Materi Keempat: Pembelajaran Aspek Hukum Dalam Bisnis. Materi ini menegaskan akan pentingnya mempertimbangkan aspek hukum dalam bisnis melalui tindakan-tindakan yang tidak bertentangan dengan hukum baik secara pidana maupun perdata. Secara pidana yang harus diperhatikan misalnya tentang jaminan kandungan produk cemilan yang tidak mengandung bahan berbahaya yang dapat berakibat pada gangguan kesehatan hingga kematian pada konsumen. Sedangkan secara perdata misalnya tentang pentingnya penggunaan merk dagang secara mandiri tanpa melalui duplikasi dari produk lain. Disamping itu pula diperhatikan tentang aspek Hak Kekayaan Intelektual yang mungkin saja dapat dimiliki oleh kelompok pengrajin sebagai karya orisinal yang perlu memperoleh hak paten. Hasilnya menunjukkan: meningkatnya pemahaman anggota kelompok tentang pentingnya aspek hukum dalam bisnis sehingga dapat menjalankan operasional bisnis tanpa melakukan pelanggaran hukum baik secara pidana maupun perdata.

5. Materi Kelima: Aspek Manajemen Usaha. Materi ini menegaskan akan pentingnya manajemen usaha yang profesional dalam operasional bisnis. Manajemen sebagai kunci kesuksesan bisnis dilakukan melalui praktek fungsi-fungsi manajemen yang meliputi: perencanaan, pengorganisasian, pelaksanaan, pemasaran dan evaluasi untuk keberlanjutan usaha. Disamping fungsi manajemen dibahas pula dalam materi ini menyangkut unsur-unsur manajemen yang meliputi: manusia (man), bahan (material), mesin (machine), uang (money) dan pasar (market). Kombinasi antara fungsi manajemen dan unsur manajemen menghasilkan efektifitas dan efisiensi manajemen bisnis yang berkelanjutan. Hasilnya menunjukkan: kelompok masyarakat sebagai sasaran memperoleh pengetahuan baru tentang manajemen bisnis pengolahan labu kuning sebagai produk cemilan yang sehat dan higienis. Bekal ilmu manajemen ini tentunya sangat berharga karena kelompok masyarakat langsung dapat mempraktekkan fungsi dan unsur manajemen secara bersamaan yang didampingi oleh tim pelaksana KKN-PPM dan seluruh mahasiswa peserta.

6. Materi Keenam: Teori dan Praktek Penyusunan Studi Kelayakan Bisnis Cemilan Labu Kuning Bagi Kelompok Masyarakat Pengrajin. Pada materi ini anggota kelompok sasaran memperoleh pengetahuan dan pengalaman bagaimana menyusun program kerja yang realistis berdasarkan kondisi internal dan kondisi eksternal yang dihadapi oleh kelompok pengrajin pada masa sekarang dan perencanaan bisnis jangka panjang. Pengalaman tersebut meyakinkan anggota kelompok tentang prospek bisnis yang menjanjikan dan pasti untuk produk cemilan labu kuning yang direncanakan secara realistis, terencana dan sistematis. Dalam materi ini juga dipraktekkan tentang penyusunan rencana bisnis secara periode bulanan dan tahunan. Praktek juga difokuskan pada penyusunan tahapan-tahapan dalam mencapai rencana secara periodik. Kegiatan lainnya adalah simulasi bagaimana menangani permasalahan yang muncul baik secara internal maupun eksternal dan bagaimana pula menghadapi lingkungan bisnis eksternal yang berubah dengan sangat cepat. Hasilnya menunjukkan: Terjadi peningkatan kemampuan kapasitas kelompok pengolah labu kuning dalam hal penyusunan rencana bisnis bulanan dan tahunan.

7. Materi Ketujuh: Praktek Inovasi Produk Cemilan Labu Kuning. Praktek untuk inovasi produk dilakukan oleh praktisi, dalam hal ini salah satu mitra yang memiliki pengetahuan dan pengalaman luas tentang produksi cemilan labu kuning sesuai dengan standarisasi pasar moderen. Semua peserta mengikuti dengan baik dan mempraktekkan inovasi tersebut untuk menghasilkan produkproduk terbaru tentang cemilan labu kuning. Inovasi dilakukan dalam bentuk cemilan aneka rasa yaitu rasa pedas, manis dan asin sebagai inovasi rasa baru untuk cemilan labu kuning. Inovasi tersebut juga merupakan peluang bagi kelompok usaha untuk memproduksi cemilan aneka rasa khas desa Barakati.

Hasil kegiatan bimbingan teknis proses pembuatan cemilan labu kuning menjadi ragam produk yang sehat dan higienis di Desa Barakati memberikan pengalaman dan penguatan terhadap anggota kelompok pengrajin akan besarnya potensi bisnis produk cemilan labu kuning. Disamping itu pula bimbingan teknis memberikan bekal pengetahuan manajemen pengolahan usaha beserta implementasinya pada kegiatan usaha. Hal penting lainnya dari bimbingan teknis adalah pengetahuan bagi kelompok usaha juga diberikan mengenai aspek hukum dalam usaha. Hal tersebut untuk memberikan jaminan kepastian hukum maupun legalitas terhadap usaha yang dijalankan, juga untuk memberikan pengetahuan tentang berbagai resiko yang mungkin 
saja terjadi dalam bisnis. Disamping itu pula peserta sebagai kelompok sasaran dibekali tentang kemitraan dengan pihak usaha lain, perencanaan pasar dan sebagainya. Kegiatan bimbingan teknis dilanjutkan pula dengan teori dan praktek penyusunan rencana binis bagi sektor usaha kecil menengah yang diikuti oleh seluruh peserta anggota kelompok.

\section{KESIMPULAN}

Melalui program KKN-PPM di Desa Barakati tahun 2017 telah banyak memberikan pengetahuan dan pengalaman empirik bagi tim dosen pelaksana, mahasiswa dan utamaya bagi kelompok sasaran. Berbagai manfaat tersebut setidaknya dapat diuraikan sebagai berikut:

1) Mahasiswa mampu mengaplikasikan teori dalam praktek dari berbagai disiplin ilmu yaitu pertanian, ekonomi, ilmu pengetahuan alam dan ilmu hukum. Disamping itu pula bagi seluruh mahasiswa peserta sebagai perwujudan sikap positif dan produktif mahasiswa bersama kelompok pengolah labu kuning dan masyarakat pada umumnya di desa Barakati. Mulai terbiasanya mahasiswa dengan sikap peduli, empati kepada masalahmasalah sosial di masyarakat, utamanya dalam masalah pemberdayaan masyarakat petani labu kuning dan kelompok masyarakat pengolah labu kuning.

2) Terwujudnya sinergi antara kelompok pengrajin dengan konsumen produk cemilan labu kuning pada wilayah sasaran dan sekitarnya. Pemerintah setempat telah terbantu dalam hal meningkatkan pemberdayaan masyarakat kelompok petani labu kuning dan kelompok pengolah cemilan labu kuning.

3) Kegiatan ini sebagai kontribusi nyata dari perguruan tinggi dan tim dosen pelaksana dalam hal implementasi keilmuan untuk menjawab masalah mendasar yang dihadapi oleh kelompok sasaran di desa Barakati.

Berdasarkan implementasi dan hasil akhir kegiatan maka tim pelaksana mengusulkan beberapa aspek sebagai berikut:

1) Program KKN-PPM harus tetap diadakan dengan pada masa yang akan datang karena telah terbukti berkontribusi nyata bagi masyarakat, pemerintah desa, dosen, mahasiswa serta perguruan tinggi.

2) Program KKN-PPM perlu diperluas di berbagai wilayah terpencil untuk mengangkat berbagai potensi desa yang masih terpendam sebagai bentuk komitmen perguruan tinggi dalam program pengabdian kepada masyarakat.

3) Disarankan setelah selesainya kegiatan KKN-PPM 2017 dapat dikembangkan lagi melalui Program Kemitraan Wilayah (PKW) untuk terus menguatkan potensi labu kuning sebagai ragam produk cemilan yang sehat dan higienis khas desa Barakati Kecamatan Batudaa Pantai Kabupaten Gorontalo.

\section{UCAPAN TERIMAKASIH}

Setelah melalui berbagai tahapan proses kegiaan KKN-PPM Tahun 2017 maka hasil kegiatan ini telah memberikan manfaat bagi kelompok petani dan kelompok ibu-ibu sebagai sasaran. Disamping itu pula manfaat bagi pemerintah Desa, mahasiswa, dosen dan perguruan tinggi. Oleh karena itu pada kesempatan ini kami menyampaikan ucapan terimakasih disampaikan kepada 1) Direktorat jenderal pengabdian masyarakat Kementerian Ristek dan Dikti Republik Indonesia, 2) Pimpinan dan seluruh staf Lembaga Penelitian dan Pengabdian masyarakat Universitas Negeri Gorontalo, 3) Pemerintah Kabupaten Gorontalo, Kecamatan Batudaa Pantai dan pemerintah desa Barakati, 4) Kelompok Petani Labu Kuning dan Ibu-ibu kelompok pengolah ragam produk cemilan Desa Barakati, 5) Tim pelaksana dan mahasiswa peserta KKN-PPM. Semoga hasil kegiatan pengadian ini mampu memberikan manfaat jangka panjang bagi kelompok petani dan pengolah labu kuning serta masyarakat sekitarnya.

\section{DAFTAR PUSTAKA}

Gardjito, M (Editor). 2006. Labu Kuning Sumber Karbonhidrat Kaya Vitamin A. Yogyakarta: Tridatu Visi Komunikasi

Sudarto, Y. 2000. Budidaya Waluh. Yogyakarta: Kanisius

Surat keputusan Kepala Badan Pengawas Obat Dan Makanan Republik Indonesia No. HK.00.05.52.4040 tanggal 9 Oktober 2006 tentang Kategori Pangan

Panduan Pelaksanaan Penelitian dan Pengabdian Kepada Masyarakat di Perguruan Tinggi Edisi XI 2017

Usmiati, S.S Yuliani dan Setiyanto, 2005. Karakteristik Proksimat dan Profil Warna Tepung Labu Kuning. Bogor : Balai Besar Penelitian dan Pengembangan Pascapanen Pertanian

Widayati, E \& Damayanti, W. 2007. Aneka Pengolahan dari Labu Kuning. Jakarta: Trubus Agrisarana 


\section{Dokumentasi.}

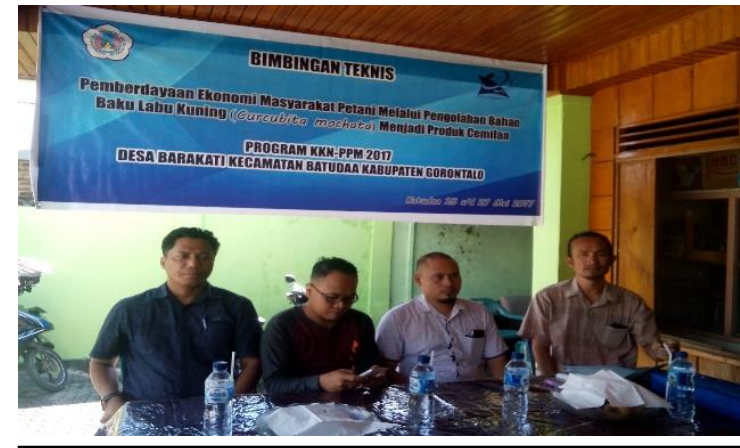

Gambar 1. Tahap/Proses Bimbingan Teknis

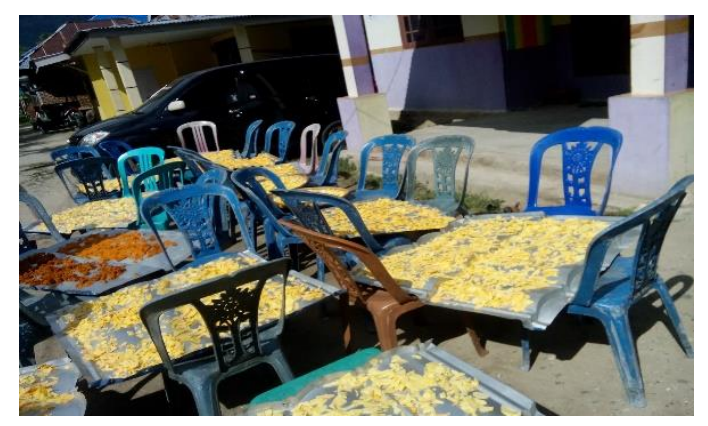

Gambar 3. Tahap/Proses pemotongan dan pengeringan

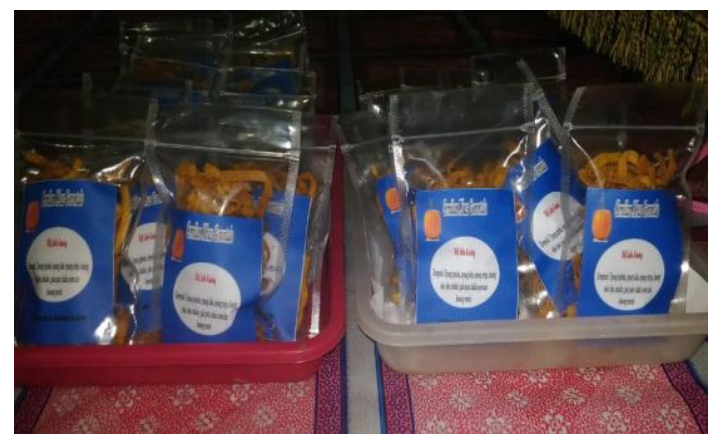

Gambar 5. Tahap/Proses pengemasan produk cemilan labu kuning

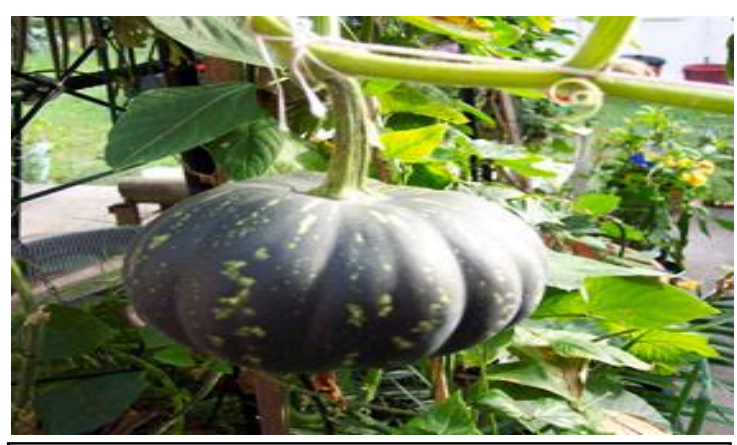

Gambar 2. Tahap/Proses pemilihan labu kuning

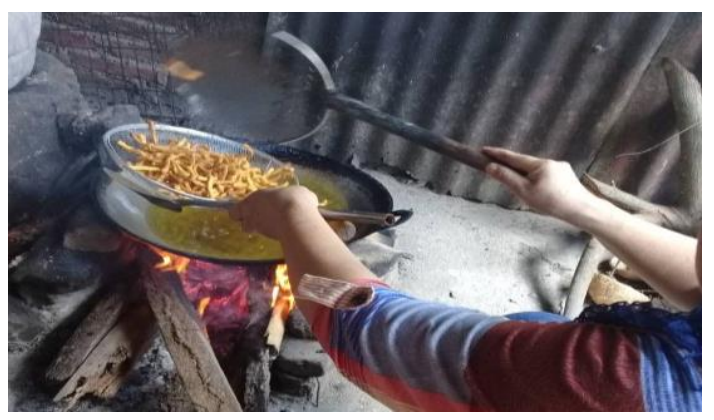

Gambar 4. Tahap/Proses penggorengan

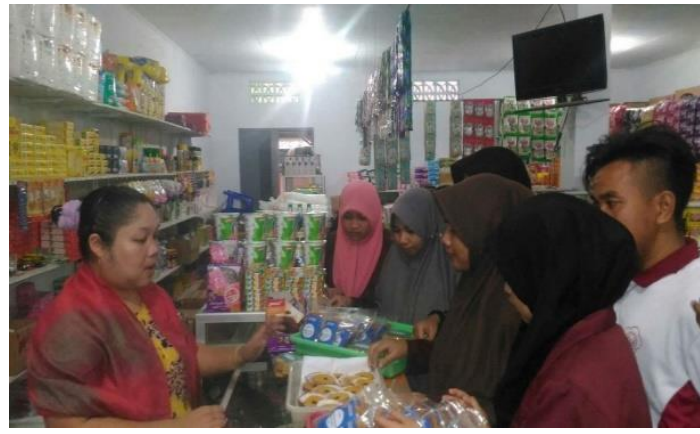

Gambar 6. Tahap/Proses pemasaran 